\title{
PENINGKATAN KETERAMPILAN MOTORIK HALUS MELALUI PERMAINAN SAINS BILLON PADA KELOMPOK B
}

\author{
(Penelitian Single Case Experimental pada Kelompok B TK Al Munawaroh \\ Banjarsari)
}

\author{
Revalina Rizky Rinjany Sastra Miharja \\ Universitas Pendidikan Indonesia \\ revalinarinjany13@gmail.com
}

\begin{abstract}
ABSTRAK
Peningkatan keterampilan motorik halus melalui permainan sains billon pada kelompok B TK Al Munawaroh Banjarsari. Penelitian ini dilatarbelakangi hasil pengamatan dan pengalaman peneliti bahwa kemampuan motorik halus pada anak kelompok B TK Al Munawaroh Banjarsari masih rendah. Dengan keterbatasan media yang ada di sekolah, kegiatan pembelajaran yang monoton, serta kurangnya stimulus yang dilakukan karena lembaga lebih mengutamakan calistung untuk peserta didiknya, dalam peningkatan keterampilan motorik halus menjadi kurang maksimal. Penelitian ini menggunakan metode single case experimental dengan partisipan empat orang anak berusia lima sampai enam tahun berjenis kelamin laki-laki dua orang dan berjenis kelamin perempuan dua orang yang dilibatkan dalam penelitian keterampilan motorik halus melalui permainan sains billon. Teknik pengumpulan data menggunakan lembar observasi, dan dokumentasi, sedangkan untuk teknik analisi data menggunakan statistik deskriptif. Kesimpulan hasil penelitian ini adalan penerapan permainan sains billon untuk peningkatan keterampilan motorik halus pada kelompok B TK Al Munawaroh Banjarsari. Kemampuan keterampilan motorik halus anak sebelum diberi intervesi belum berkembang (BB), pada intervensi 1 mulai berkembang (MB), dan intervensi 2 berkembang sesuai harapan (BSH). Dari uraian tersebut dapat ditarik kesimpulan penerapan permainan sains billon dapat meningkatkan keterampilan motorik halus kelompok B TK Al Munawaroh Banjarsari.
\end{abstract}

Kata Kunci: Keterampilan Motorik Halus: Permainan Sains Billon: Anak Usia Dini

\begin{abstract}
Improving fine motor skills through billon science games in group B Al Munawaroh kindergarten Banjarsari. This research is motivated by the results of observations and experiences of researchers that the ability of fine motor skills in children in group B Al Munawaroh kindergarten Banjarsari is still low. With the limitations of the existing media in schools, monotonous learning activities, and the lack of stimulus carried out because institutions prioritize calistung for their students, in increasing fine motor skills becomes less than the maximum. This study uses a single case experimental method with four children aged five to six years, two male sex and two female sex who are involved in fine motor skills research through billon science games. The data collection technique used observation sheets, and documentation, while the data analysis technique used descriptive statistics. The conclusion of this research is the application of billon science games to improve fine motor skills in group B TK Al Munawaroh Banjarsari. The ability of fine motor skills of children before given intervention has not yet developed (BB), in intervention 1 begins to develop (MB), and intervention 2 develops as expected (BSH). From this description it can be concluded that the application of billon science games can improve fine motor skills in group B TK Al Munawaroh Banjarsari.
\end{abstract}

Keywords: fine motor skills; billon science games; children. 


\section{PENDAHULUAN}

Lingkungan yang baik bagi proses pertumbuhan dan perkembangan anak salah satunya adalah sekolah. Sekolah dapat membantu memberikan stimulus pendidikan yang baik bagi anak dalam mengoptimalkan pertumbuhan dan perkembangannya. Proses pembelajaran anak usia dini di sekolah dapat dijadikan sarana untuk menstimulasi berbagai aspek perkembangan anak, melalui kegiatan bermain diharapkan seluruh potensi kecerdasan anak dapat dikembangkan. Selain itu, kegiatan bermain bagi anak sangat berpengaruh pada perkembangannya (Latif, M dkk. 2013, hlm 110).

Berdasarkan pengamatan di TK Al Munawaroh Banjarsari terhadap kondisi fisik motorik anak didik yang masih kurang berkembang khususnya motorik halus, pada saat observasi peneliti melihat banyaknya kekurangan pada perkembangan motorik halus, dimana anak kurang berkonsentrasi dalam kegiatan belajar yang mendukung keterampilan motorik halus. Sehingga peneliti ingin mengembangkan motorik halus anak didik melalui penerapan permainan sains agar anak tidak mudah bosen dalam kegiatan belajar yang melatih motorik halusnya.

Upaya meningkatkan motorik halus melalui permainan sains billon adalah paling tepat digunakan dalam perkembangan anak, karena anak terlibat langsung dalam membuat permainan sains billon, melalui kegiatan membuat permainan sains billon diharapkan agar anak aktif dalam mengikuti kegiatan pembelajaran dan kegiatan membuat permainan sains menjadikan kegiatan yang menyenangkan dan memberi kesenangan.
Kegiatan dalam proses pembuatan permainan sains billon dapat mendorong anak untuk mengembangkan daya cipta yang ada di dalam dirinya. Kemampuan dalam motorik halus anak dapat mengembangkan otot-otot jari tangan. Dengan proses pembuatan permainan sains billon anak akan melatih otot-otot dan melatih keterampilan gerakan. Anak juga dapat melatih gerakan motorik halus dengan membuat permainan sains billon menggunakan bahan bekas.

Ditinjau dari penelitian terdahulu yang dilakukan oleh Suwarma R, dkk (2015) dengan judul "Balloon Powered Car Sebagai Media Pembelajaran IPA Berbasis STEM (Science, Technology, Engineering, And Mathematics)" , penelitian tersebut menunjukan bahwa permainan sains sangat mengoptimalkan dalam meningkatkan pembelajaran IPA berbasis STEM. Febriyani, P (2016) "Peningkatan Kemampuan Motorik Halus Anak Usia Dini Melalui Penerapan Permainan Sains di Taman Kanak-Kanak", penelitian tersebut menunjukan bahwa penerapan permainan sains merupakan salah satu sumber kegiatan yang dapat dioptimalkan untuk meningkatkan keterampilam motorik halus anak.

Dari penelitian tersebut dapat diketahui bahwa permainan sains merupakan sumber belajar yang sangat efektif dan bermanfaat untuk digunakan di PAUD, karena belajar dengan menggunakan permainan sains mampu memberikan pengalaman bagi anak dan dapat meningkatkan keterampilan motorik halus anak. Maka dari itu, peneliti memanfaatkan permainan sains billon sebagai sumber belajar yang digunakan pada penelitian ini karena pada penelitian terdahulu yang sudah dipaparkan sebelumnya permainan sains lebih umum 
sebagai sumber belajar anak belum diintegrasikan pada keterampilan motorik halus anak usia dini, maka secara khusus peneliti memfokuskan penelitian ini pada keterampilan motorik halus anak usia dini.

Maka dari itu mengacu pada latar belakang masalah dan penelitian yang sudah dilakukan sebelumnya, pada akhirnya peneliti melakukan penelitian Single Case Experimental dengan judul "Peningkatan Keterampilan Motorik Halus Melalui Permainan Sains Billon pada Kelompok B TK Al Munawaroh Banjarsari”.

a. Pendidikan Anak Usia Dini

1) Hakikat Pendidikan Anak Usia Dini

Menurut Tadkiroatun, M (2008, hlm 4) Pendidikan anak usia dini merupakan pendidikan yang diselenggarakan untuk mengembangkan keterampilan yang merupakan pendidikan dasar serta mengembangkan diri secara utuh sesuai dengan asas pendidikan sedini mungkin dan sepanjang hayat. Aspek yang dikembangkan dalam pendidikan anak usia dini adalah aspek pengembangan pembiasaan meliputi sosial, emosi, kemandirian, moral, dan nilai-nilai agama, serta pengembangan kemampuan dasar yangmeliputi pengembangan bahasa, kognitif, dan fisik motorik. Lebih jelasnya menurut Undang Undang Republik Indonesia Nomor 20 Tahun 2003, bab II pasal 3 tentang Sistem Pendidikan Nasional ditetapkan bahwa

"Pendidikan nasional berfungsi mengembangkan keterampilan dan membentuk watak serta peradaban bangsa yang bermartabat dalam rangka mencerdaskan kehidupan bangsa, bertujuan untuk berkembangnya potensi peserta didik agar menjadi manusia yang beriman dan bertaqwa pada Tuhan Yang Maha Esa, berakhlak mulia, sehat, berilmu, cakap, kreatif, mandiri, dan menjadi warga negara yang demokratis serta bertanggung jawab".

Sejalan dengan pengertian tersebut, Rakimahwati dkk (2018, hlm.103) mengungkapkan bahwa "Anak usia dini adalah anak yang masuk dalam rentang usia 0-6 tahun yang terbagi menjadi tiga kelompok bayi hingga umur 2 tahun, kelompok umur 3 tahun hingga kelompok umur 5 tahun, dan kelompok umur 6 tahun. Dengan demikian dapat disimpulkan bahwa anak usia dini merupakan individu yang sedang berada dalam proses pertumbuhan dan perkembangan dan memerlukan upaya pendidikan dalam rangka optimalisasi seluruh aspek perkembangannya tersebut.

Menurut Murtining (2018, hlm. 29) "Pendidikan anak usia dini merupakan pendidikan yang diselenggarakan untuk mengembangkan keterampilan yang merupakan pendidikan dasar serta mengembangkan diri secara utuh sesuai dengan asas pendidikan sedini mungkin dan sepanjang hayat". Sedangkan menurut Sujiono (2013, hlm. 16), pendidikan anak usia dini pada hakikatnya adalah "Layanan yang diberikan pada anak sedini mungkin sejak anak dilahirkan kedunia ini sampai lebih kurang anak berusia enam-delapan tahun. Pendidikan pada masa-masa ini merupakan sesuatu hal yang penting untuk mendapatkan perhatian dari semua pihak yang bertanggungjawab terhadap tumbuh kembang anak, terutama orangtua dan atau orang dewasa lainnya yang berada dekat dengan anak". Maka dari itu, pendidikan anak usia dini sangat penting dan dibutuhkan oleh anak dalam 
membantu proses tumbuh kembangnya sehingga anak dapat tumbuh dan berkembang secara optimal sesuai dengan usianya.

2) Tujuan dan Fungsi Pendidikan Anak Usia Dini

Tujuan pendidikan anak usia dini secara umum adalah "Mengembangkan berbagai potensi anak sejak dini sebagai persiapan untuk hidup dan dapat menyesuaikan diri dengan lingkungannya" (Sujiono, 2013, hlm 48). Menambahkan penjelasan sebelumnya mengenai tujuan pendidikan anak usia dini, untuk mengetahui lebih lanjut maka dipaparkan oleh Ulfah $\mathrm{F}$ (dalam jurnal Fatimah dan Rohmah) bahwa tujuan utama pendidikan anak usia dini untuk membentuk anak Indonesia yang berkualitas, yaitu anak yang tumbuh dan berkembang sesuai dengan tingkat perkembangannya sehingga memiliki kesiapan yang optimal di dalam memasuki pendidikan dasar, dan tujuan lainnya untuk membantu enyiapkan anak mencapai kesiapan belajar (akademik) di sekolah, sehingga dapat mengurangi usia putus sekolah dan mampu bersaing secara sehat di jenjang pendidikan berikutnya. Maka dari itu, tujuan pendidikan anak usia dini adalah mampu mengembangkan berbagai potensi yang dimiliki anak sejak usia dini dan juga mampu mngembangkan berbagai aspek kepribadiannya.

b. Keterampilan Motorik Halus

1) Pengertian Keterampilan Motorik Halus

Menurut Susanto (2011 : 164) motorik halus adalah gerakan halus yang melibatkan bagian-bagian tertentu saja yang dilakukan oleh otot-otot kecil saja, karena tidak memerlukan tenaga, Namun begitu gerakan yang halus ini memerlukan koordinasi yang cermat (dalam jurnal Indraswari). Sementara itu menurut Soetjiningsih (1995: 117) gerakan motorik halus yaitu gerakan yang melibatkan bagian-bagian tubuh tertentu saja dan dilakukan otot-otot kecil, tetapi diperlukan koordinasi yang cermat, contohnya: memegang benda kecil dengan jari telunjuk dan ibu jari, memasukkan benda kedalam botol, menggambar, dan lain-lain. Menurut Santrock (2007: 216) dalam jurnal Rakimahwati, dkk "keterampilan motorik halus merupakan keterampilan motorik yang melibatkan gerakan yang diatur secara halus".

Menurut Rahyubi (2012) dalam jurnal Suriantoso dkk, aktivitas motorik halus (fine motor activity) adalah keterampilan yang memerlukan kemampuan untuk mengkoordinasi kan atau mengatur otot-otot kecil/halus. Misalnya, berkaitan dengan gerakan mata dan tangan yang efisien, tepat dan adaptif. Menurut Sariantoso untuk meningkatkan kemampuan motorik halus seseorang, maka dibutuhkan suatu proses pembelajaran melalui latihan yang bertahap atau melalui fase-fase tertentu.

Berdasarkan beberapa pendapat diatas, maka peneliti dapat menjelaskan bahwa motorik halus adalah gerakan yang hanya melibatkan bagian-bagian tubuh tertentu saja dan dilakukan oleh otot-otot kecil, seperti keterampilan menggunakan jari jemari tangan dan gerakan pergelangan tangan yang tepat. Oleh karena itu, gerakan ini tidak terlalu membutuhkan tenaga, namun gerakan ini membutuhkan koordinasi mata dan tangan yang cermat. Semakin baiknya gerakan mototrik halus anak membuat anak dapat berkreasi, seperti 
menggunting kertas, menggambar, mewarnai, serta menganyam. Namun tidak semua anak memiliki kematangan untuk menguasai kemampuan ini pada tahap yang sama.

c. Permainan Sains Anak Usia Dini

1) Pengertian Permainan Sains Untuk Anak Usia Dini

Nauman (dalam Yulianti D, 2010, hal 18) sains adalah produk dan proses. Sebagai produk, sains adalah batang tubuh pengetahuan yang terorganisir dengan baik mengenai fisik alami. Sebagai proses, sains mencakup, menelusuri, mengamati dan melakukan percobaan.

Dalam sains, terdapat tiga unsur utama, yaitu sikap manusia, proses atau metodologi, dan hasil yang satu sama lain tidak dapat dipisahkan. Sikap manusia yang selalu ingin tau tentang benda-benda, makhluk hidup, dan hubungan sebab akibatnya akan menimbulkan permasalahanpermasalahan yang selalu ingin dipecahkan dengan prosedur yang benar. Prosedur tersebut meliputi metode ilmiah. pengukuran, dan akhirnya menghasilkan produk berupa faktafakta, prinsip-prinsip, teori, hukum, dan sebagainya.Metode ilmiah mencakup perumusan hipotesis, perancangan percobaan, evaluasi atau pengukuran, dan akhirnya menghasilkan produk berupa fakta-fakta, prinsip-prinsip, teori, hukum, dan sebagainya.

Sains membiasakan anak-anak megikuti tahap-tahap eksperimen dan tidak boleh menyambunyikan suatu kegagalan. Artinya, sains dapat melatih mental positif, berfikir logis, dan urut ( sistematis ). Disamping itu, sains dapat pula melatih anak untuk bersikap cermat karna anak harus mengamati, menyusun prediksi, dan mengambil keputusan.

2) Jenis-jenis Permainan Sains Anak Usia Dini

Berikut ini beberapa permainan sains anak usia dini yang dapat digunakan untuk kegiatan pembelajaran anak usia dini khususnya pembelajaran sains yang dapat membantu meningkatkan aspek perkembangan. Menurut Triharso, A (2013 : 53) permainan-permainan itu sendiri dapat dikreasikan lebih lanjut, yang terpenting permainan yang dipilih tetap mengandung nilai-nilai kreativitas, edukasi, kompetisi, sportivitas, semangat kebersamaan, dan sebagainya.

Jenis-jenis permainan sains untuk anak usia dini diantara lain : nemancing ikan, detektif kebun, menyortir bijibijian, billon, bermain warna dll. Anak memiliki rasa ingin tahu yang sangat tinggi. Rasa ingin tahu tersebut perlu difasilitasi oleh guru ataupun orang dewasa yang berfungsi sebagai guru anak. Yang utama adalah anak tidak dipaksakan untuk belajar. Anak dapat belajar apa saja sejak dini termasuk belajar sains. Menurut Triharso, A (2013 : 39) mengenalkan sains sejak usia dini untuk menumbuhkan kesadaran terhadap lingkungan sangat penting. Anak akan terus memiliki rasa ingin tahu dan mengeksplorasi lingkungannya.

\section{METODE PENELITIAN}

Penelitian ini menggunakan pendekatan kuantitatif deskriptif dengan metode single case experimental, bertujuan untuk mendeskripsikan keterampilan motorik halus melalui permainan sains billon pada Kelompok B TK Al Munawaroh Banjarsari. 
Menurut Creswell (2016, hlm. 5), "Penelitian kuantitatif merupakan metodemetode untuk menguji teori tertentu dengan cara meneliti hubungan antar variabel. Penelitian ini mengukur dan mendeskripsikan tentang keterampilan motorik halus anak usia lima sampai dengan enam tahun di kelompok B TK Al Munawaroh Banjarsari.

Instrumen dalam penelitian ini menggunakan lembar observasi mengenai keterampilan motorik halus anak. Keterampilan motorik halus tersebut dikembangkan ke dalam indikator dan deskriptor-deskriptor untuk mengobservasi keterampilan motorik halus yang ditunjukan oleh anak pada kegiatan permainan sains billon.

Desain yang digunakan dalam penelitian ini yakni single case experimental desain reserval, dengan jenis A-B-A. Desain A-B-A merupakan desain penelitian eksperimen subyek tunggal. Desain tersebut menunjukkan adanya kontrol terhadap variabel bebas yang lebih kuat, dan merupakan pengulangan dari desain A-B. Pada desain ini hasil penelitian berusaha menunjukkan hubunganfungsional antara variabel terikat dan bebas lebih menyakinkan, dengan membandingkan dua kondisi baseline sebelum dan sesudah intervensi. (Sunanto, 2005, hlm. 63). Dengan kata lain, “...this design strategy provides for two occasions (B to A and then A to B) for demonstrating the positive affects of the treatment variable." (Barlow, 1984 : 158). Desain A-B-A dipilih oleh peneliti karena dengan adanya pengukuran kondisi baseline yang kedua maka peneliti telah melakukan kontrol untuk fase intervensi sehingga memungkinkan untuk menarik kesimpulan adanya hubungan fungsional antara variabel bebas dan variabel terikat (Sunanto, J, dkk. 2005. Hlm 59).

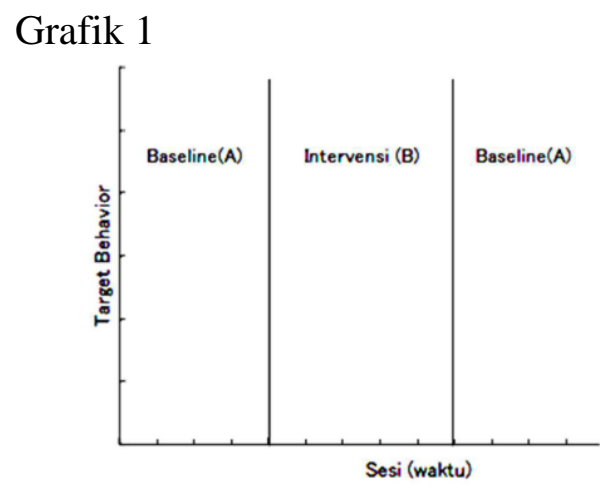

Penjelasan grafik 3.1. Huruf A digunakan untuk menunjukkan kondisi baseline, data dicatat beberapa kali dalam kondisi natural (sebelum mendapat intervensi). Kondisi baseline (A) inilah sering ada di fase pertama untuk membandingkan data setelah diberikan intervensi. Huruf B menunjukkan pengukuran target behavior, intervensi telah diberikan. Intervensi tersebut dapat bervariasi, artinya dalam fase (B) mungkin diberikan lebih dari satu fase.

\section{HASIL DAN PEMBAHASAN}

\section{Grafik 4.1}

Perkembangan Keterampilan Motorik Halus Subjek 1 pada Indikator 1

(Mampu menggerakan 10 jari)

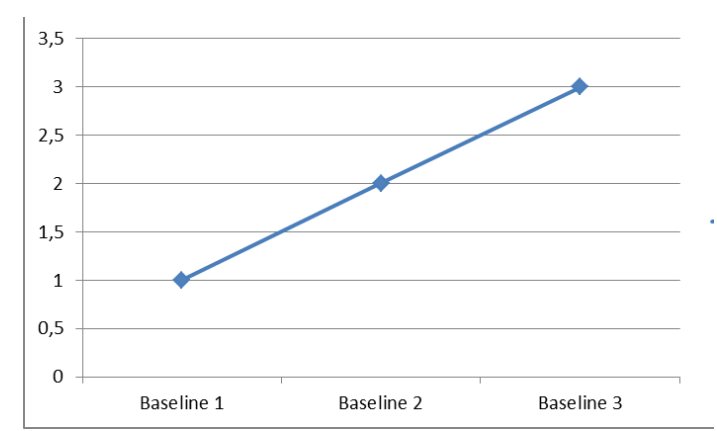


Pada grafik 4.1 subjek 1 pada indikator 1 (mampu menggerakan 10 jari), menunjukan peningkatan yang konsinten setiap baselinenya. Subjek 1 tidak mengalami kesulitan dalam meningkatkan keterampilan motorik halus pada indikator 1 (mampu menggerakan 10 jari. Subjek 1 menunjukan skor tertinggi pada indikator 1 dengan memperoleh skor 3, karena subjek 1 berhasil menyelesaikan tiga ITO yaitu menggerakan jari tangan kirinya untuk memegang dan mengambil bahan-bahan (ITO1), menggerakan jari tangan kanannya untuk menyusun permainan sains billon (ITO2), memindahkan benda dari tangan yang satu ke tangan yang lain (ITO3).

\section{Grafik 4.2}

Perkembangan Keterampilan Motorik Halus Subjek 1 pada Indikator 2

(Terampil dalam menggerakan kedua tangan)

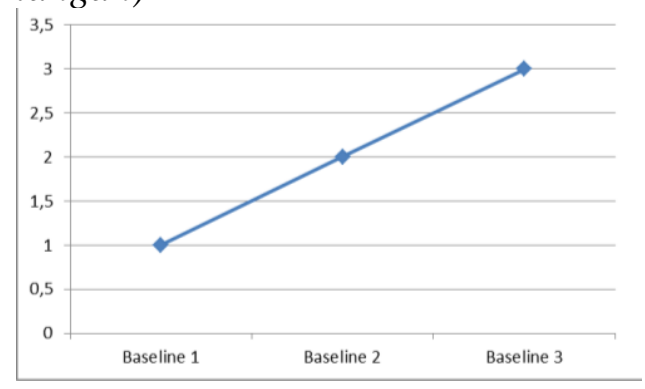

Pada pengamatan grafik 4.2 subjek 1 menunjukan bahwa keterampilan motorik halus pada indikator 2 (terampil dalam menggerakan kedua tangan) yang meningkat dari baseline-baseline sebelumnya, pada baseline 1 subjek 1 hanya mampu menyelesaikan 1 ITO, pada baseline selanjutnya subjek 1 menyelesaikan 2 ITO, dan pada baseline terakhir subjek 1 menyelesaikan semua ITO sehingga subjek 1 pada indikator 2 memperoleh skor tertinggi yaitu 3.

\section{Grafik 4.3}

Perkembangan Keterampilan Motorik Halus Subjek 1 pada Indikator 3

(Mata fokus dan searah dengan gerakan tangannya)

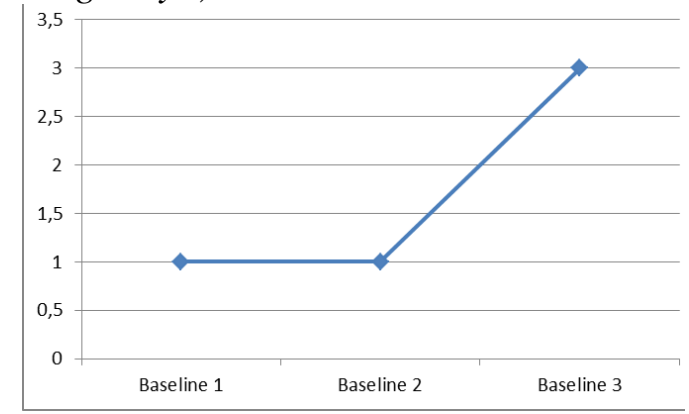

Dari grafik 4.3 diketahui bahwa Subjek 1 pada indikator 3 pada baseline 1 dan baseline 2 sama sekali tidak menunjukan adanya peningkatan, tetapi pada baseline 3 pada indikator 3 (mata fokus dan searah dengan gerakan tangannya) subjek 1 menunjukan peningkatan yang sangat signifikan mampu menyelesaikan semua ITO pada indikator 3 .

\section{Grafik 4.4}

Perkembangan Keterampilan Motorik Halus Subjek 2 pada Indikator 1

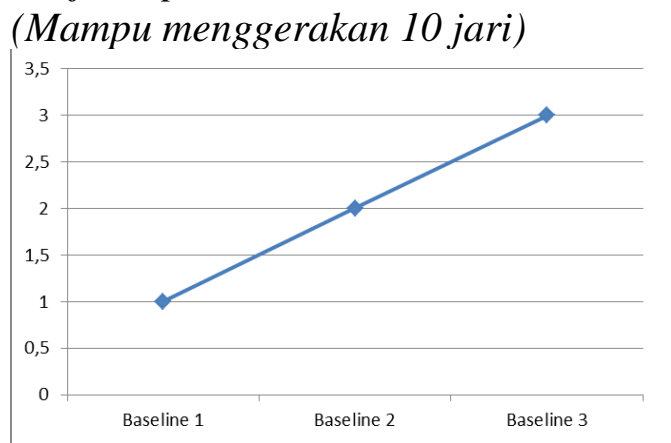


Revalina Rizky Rinjany Sastra Miharja . PENINGKATAN KETERAMPILAN MOTORIK HALUS MELALUI PERMAINAN SAINS BILLON PADA KELOMPOK B (Penelitian Single Case Experimental pada Kelompok B TK Al Munawaroh Banjarsari). Early Childhood Vol. 4 No. 2, November 2020.

Subjek 2 pada indikator 1 ( mampu menggerakan 10 jari) menunjukan peningkatan yang konsinten setiap baselinenya. Subjek 2 tidak mengalami kesulitan dalam meningkatkan keterampilan motorik halus pada indikator 1 (mampu menggerakan 10 jari. Subjek 2 menunjukan skor tertinggi pada indikator 1 dengan memperoleh skor 3, karena subjek 2 berhasil menyelesaikan tiga ITO yaitu menggerakan jari tangan kirinya untuk memegang dan mengambil bahan-bahan (ITO1), menggerakan jari tangan kanannya untuk menyusun permainan sains billon (ITO2), memindahkan benda dari tangan yang satu ke tangan yang lain (ITO3).

\section{Grafik 4.5}

Perkembangan Keterampilan Motorik Halus Subjek 2 pada Indikator 2

(Terampil dalam menggerakan kedua tangan)

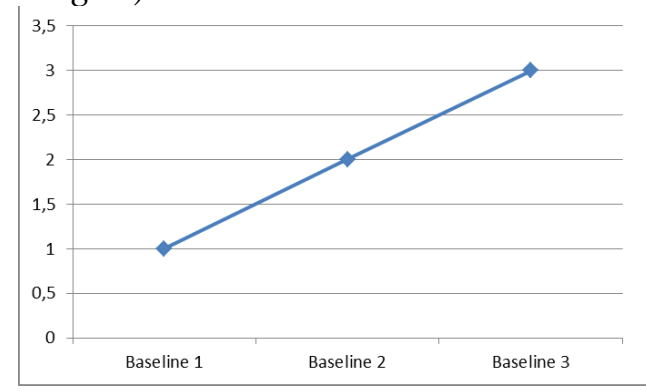

Dilihat dari grafik 4.5 subjek 2 pada indikator 2 (terampil dalam menggerakan kedua tangan menunjukan peningkatan yang stabil, subjek 2 pada baseline terakhir mampu menyelesaikan semua ITO yaitu, terampil menggerakan kedua tangan untuk memasukan tusuk sate ke dalam tutup botol yang sudah dilubangi (ITO4), terampil menggerakan kedua tangan untuk mengambil alat dan bahan (ITO5), terampil menggunakan kedua tangan saat menggunting (ITO6) dan memperoleh skor tertinggi yaitu 3 tanpa adanya kesulitan.

Grafik 4.6

Perkembangan Keterampilan Motorik Halus Subjek 2 pada Indikator 3

(Mata fokus dan searah dengan gerakan tangannya)

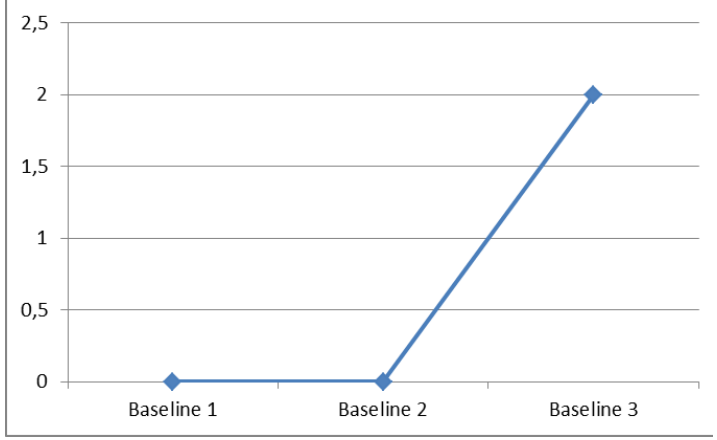

Pada indikator 3 (mata fokus dan searah dengan gerakan tangannya) dari pengamatan grafik 4.6 subjek 2 mengalami kesulitan dalam menyelesaikan ITO indikator 3 pada baseline 1 dan baseline 2, tetapi pada baseline 3 subjek 2 menunjukan peningkatan yang sangat signifikan mampu menyelesaikan dua ITO yaitu memfokuskan mata kearah gerakannya (memasukkan tusuk sate kedala tutup botol yang sudah dilubangi) (ITO7), dan anak mampu menggerakan mata dan tangannya secara bersamaan saat menggunting lurus sedotan sesuai intruksi guru (ITO9).

\section{Grafik 4.7}

Perkembangan Keterampilan Motorik Halus Subjek 3 pada Indikator 1

(Mampu menggerakan 10 jari) 


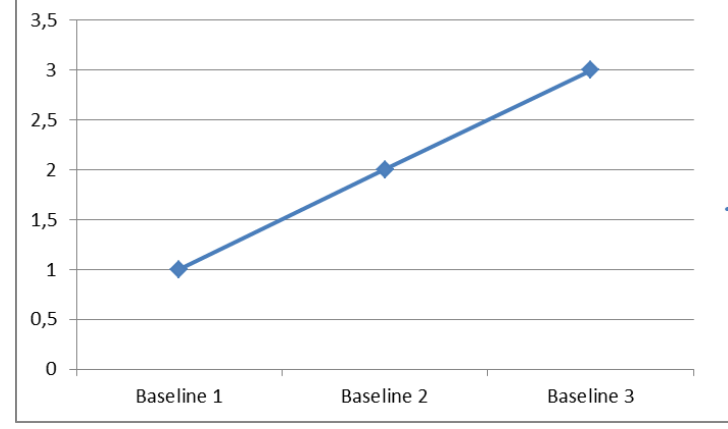

Pada grafik 4.7 subjek 3 pada indikator 1 (mampu menggerakan 10 jari), menunjukan peningkatan yang konsinten setiap baselinenya. Subjek 3 tidak mengalami kesulitan dalam meningkatkan keterampilan motorik halus pada indikator 1 (mampu menggerakan 10 jari. Subjek 3 menunjukan skor tertinggi pada indikator 1 dengan memperoleh skor 3, karena subjek 3 berhasil menyelesaikan tiga ITO yaitu menggerakan jari tangan kirinya untuk memegang dan mengambil bahan-bahan (ITO1), menggerakan jari tangan kanannya untuk menyusun permainan sains billon (ITO2), memindahkan benda dari tangan yang satu ke tangan yang lain (ITO3).

\section{Grafik 4.8}

Perkembangan Keterampilan Motorik Halus Subjek 3 pada Indikator 2

(Terampil dalam menggerakan kedua tangan)

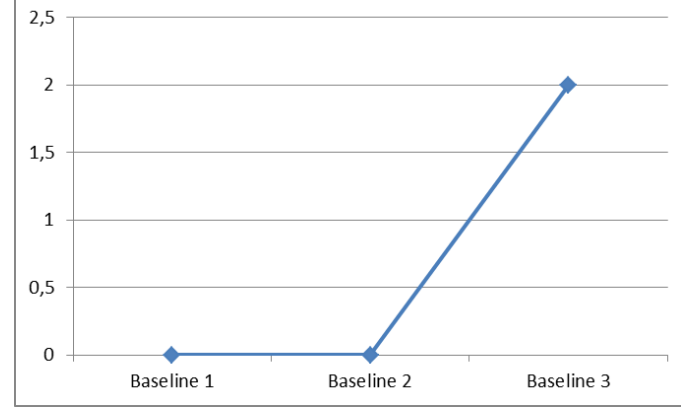

Pada grafik 4.8 indikator 2 (terampil dalam menggerakan kedua tangan) subjek 3 mengalami kesulitan dalam menyelesaikan ITO indikator 2 pada baseline 1 dan baseline 2, tetapi pada baseline 3 subjek 3 menunjukan peningkatan yang sangat signifikan mampu menyelesaikan dua ITO yaitu mampu menggerakan kedua tangan untuk mengambil alat dan bahan (ITO5), menggunakan kedua tangan saat mengunting (ITO6). Jadi, subjek 3 hanya mendapat skor 2 karena tidak dapate menyelesaikan semua ITO yang terdapat diindikator 3 .

Grafik 4.9

Perkembangan Keterampilan Motorik Halus Subjek 3 pada Indikator 3

(Mata fokus dan searah dengan gerakan tangannya)

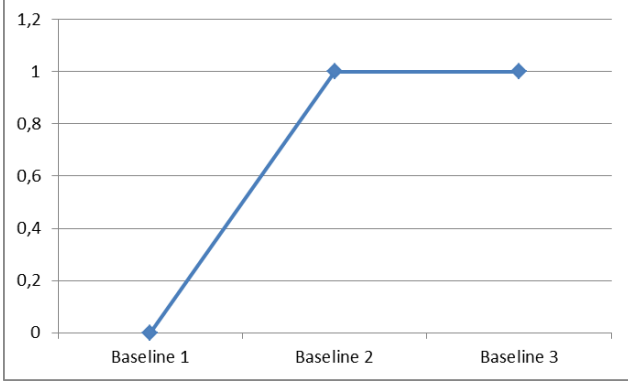

Dari grafik 4.9 subjek 3 pada indikator 3 (mata fokus dan searah dengan gerakannya) mengalami kesulitan dalam menyelesaikan ITO pada indikator 3 terlihat pada baseline 1 subjek 3 sama sekali tidak menyelesaikan ITO, dan pada baseline 2 dan 3 hanya mampu menyelesaikan satu ITO saja. 


\section{Grafik 4.10}

Perkembangan Keterampilan Motorik Halus Subjek 4 pada Indikator 1

(Mampu menggerakan 10 jari)

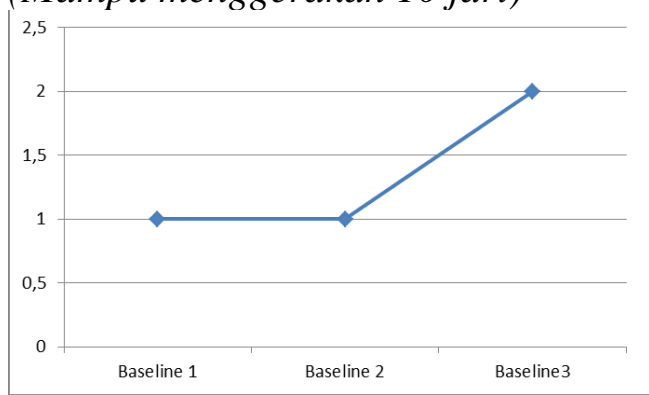

Subjek 4 pada indikator (mata fokus dan searah dengan gerakannya) mengalami kesulitan dalam menyelesaikan beberapa ITO pada indikator 3. Dilihat dari grafik 4.10 subjek 4 pada baseline 1 dan baseline 2 hanya dapat menyelesaikan satu ITO yaitu memindahkan benda dari tangan yang satu ke tangan yang lain (ITO3), dan pada baseline 3 hanya dapat menyelesaikan dua ITO yaitu menggerakan jari tangan kirinya untuk memegang dan mengambil bahan-bahan (ITO1) dan memindahkan benda dari tangan yang satu ke tangan yang lain (ITO3), Subjek 4 mendapat skor 2 karena tidak dapat menyelesaikan semua ITO pada indikator 3 .

\section{Grafik 4.11}

Perkembangan Keterampilan Motorik Halus Subjek 4 pada Indikator 2

(Terampil dalam menggerakan kedua tangan)

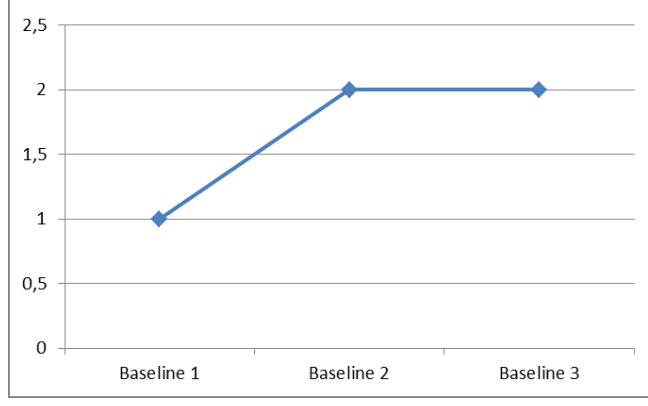

Pada pengamatan grafik 4.11 subjek 4 pada indikator 2 (terampil dalam menggerakan kedua tangan) menunjukan peningkatan dari baseline 1 ke baseline 2 dengan ditandai subjek 4 pada baseline 2 mampu menyelesaikan dua ITO yaitu terampil menggerakan kedua tangan untuk mengambil alat dan bahan (ITO5), terampil menggunakan kedua tangan saat menggunting (ITO6), sedangkan pada baseline 1 hanya menyelesaikan satu ITO yaitu terampil menggunakan kedua tangan saat menggunting (ITO6). Akan tetapi, pada baseline 3 anak mengalami sedikit kesulitan untuk menyelesaikan semua ITO pada indikator 3 sehingga subjek 4 bertahan pada skor 2 sama seperti baseline 2 .

\section{Grafik 4.12}

Perkembangan Keterampilan Motorik Halus Subjek 4 pada Indikator 3

(Mata fokus dan searah dengan gerakan tangannya)

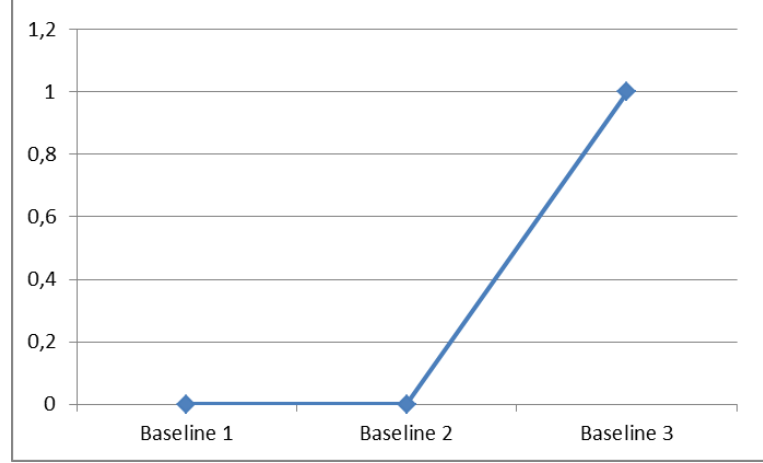


Subjek 4 mengalami kesulitan dalam peningkatan keterampilan motorik halus pada indikator 3 (mata fokus dan searah dengan gerakan tangannya). Dilihat dari grafik 4.12 subjek 4 hanya dapat menyelesaikan satu item observasi dalam kurung waktu 3 baseline.

Grafik di atas bukan menampilkam perbandingan anak per indikator, namun untuk menampilkan perkembangan anak per indikator tanpa membandingkan satu dengan yang lainnya. Dari grafik tersebut dapat diperoleh informasi bahwa perbandingan setiap baseline per indikator tiap anak semakin meningkat. Perilaku S3, S4 adanya kesulitan dalam peningkatan keterampilan motorik halus anak. Keterampilan motorik halus pada anak usia dini meliputi pergerakan jari-jemari tangan, pergerakan pergelangan tangan secara halus, koordinasi mata dan tangan.

Berdasarkan analisis terhadap keterampilan motorik halus anak usia dini di atas terdapat peningkatan skor setiap baseline, peningkatan skor setiap baseline merupakan mendekati peningkatan keterampilan motorik halus anak usia dini. Semakin tinggi skor yang didapat oleh anak maka semakin tinggi peningkatan keterampilan motorik halus dan semakin sedikit skor yang didapat oleh anak maka semakin rendah peningkatan keterampilan motorik halus anak. Skor maksimal dalam setiap item adalah 3, dan terendah adalah 0 .

Peningkatan keterampilan motorik halus anak dapat diminimalisasi dengan melalui stimulus permainan sains billon, jika didukung pula secara optimal oleh beberapa faktor yang memberikan kontribusi terhadap keterampilan motorik halus anak dibawah ini. Ada beberapa faktor yang mempengaruhi keterampilan motorik halus yaitu faktor eksternal dan faktor internal. Berdasarkan pendapat Hurlock (1979) dalam jurnal Yulianto, D (2017:120).

1) Faktor Eksternal

a. Lingkungan Keluarga

Keluarga adalah lingkungan pertama bagi anak. Keluarga yang pertama mengajarkan anak segala hal. Oleh karena itu, keluarga yang menentukan perkembangan awal anak sebelum anak mengenal lingkungan luar. Gaya pengasuhan orang tua turut mempengaruhi dalam perkembangan keterampilan motorik halus anak, karena orang tua adalah guru pertama bagi anak.

b. Lingkungan Masyarakat

Lingkungan masyarakat sekitar tempat tinggal turut memengaruhi keterampilan motorik halus anak. Apabila masyarakat sekitar cenderung individual atau anggota masyarakatnya yang cenderung sibuk, maka anak akan mempunyai sedikit kesempatan untuk bemain dengan anakanak diluar rumah.

\section{c. Lingkungan Sekolah}

Setelah lingkungan keluarga tempat belajar anak, yang selanjutnya adalah sekolah. Sekolah adalah tempat anak belajar berbagai hal termasuk dalam keterampilan motorik halus anak. Guru akan selalu membimbing, mengajarkan, dan memberi berbagai pelatihan kepada anak agar anak berkembang dengan sangat baik. Salah satunya melalui permainan sains billon.

d. Teman Sebaya

Teman sebaya turut memengaruhi keterampilan motorik halus anak, karena selain dengan keluarga anak juga berinteraksi dengan teman sebayanya. Baik di lingkungan masyarakat maupun di lingkungan sekolah. Teman sebaya berarti 
memiliki umur yang sebaaya yang menyebabkan anak dapat bermain bersama yang dapat meningkatkan keterampilan motorik halus anak.

2) Faktor Internal

Selain faktor dari luar diri anak, faktor dalam diri anak turut memengaruhi Keterampilan motorik halus anak . Sebagai contoh anak yang memiliki kekurangan dalam hal fisik, mereka cenderung terlambat dalam perkembangan motorik halusnya. Selain itu, umur, jenis kelamin, genetik, dan kelainan kromosom turut mempengaruhi keterampilan motorik halus pada anak.

\section{KESIMPULAN}

Berdasarkan hasil penelitian yang telah dilakukan di Kelompok B TK AlMunawaroh Banjarsari terkait peningkatan keterampilan motorik halus anak, peneliti dapat menyimpulkan data yang diperoleh terkait profil peningkatan keterampilan motorik halus anak melalui intervensi permainan sains billon, yakni:

1) Profil awal keterampilan motorik halus anak kelompok B TK Al-Munawaroh Banjarsari sebelum dilakukan treatment permainan sainsi billon memiliki kategori tinggi atau Belum Berkembang (BB);

2) Profil keterampilan motorik halus anak kelompok B TK Al-Munawaroh Banjarsari saat dilakukan treatment permainan sains billon memiliki kategori sedang atau Mulai Berkembang (MB);

3) Profil akhir keterampilan motorik halus anak kelompok B TK Al-Munawaroh Banjarsari sebelum dilakukan treatment permainan sains billon memiliki kategori rendah atau Berkembang Sesuai Harapan (BSH).

\section{DAFTAR PUSTAKA}

Creswell. (2016). Research Design pendekatan kualitatif, kuantitatif, dan mixed. Yogyakarta : Pustaka Pelajar.

Fatimah, F. Rohmah, N. (2016). Pola Pengelolaan Pendidikan Anak Usia Dini.

Indraswari, L. ().Peningkatan Perkembangan Motorik Halus Anak Usia Dini Melalaui Kegiatan Mozaik Di Taman Kanak-Kanak Pembina Agam. Jurnal Pesona PAUD. 1 (1). Hlm 4-3.

Latif, M dkk. (2013). Orientasi Pendidikan Anak Usia Dini. Jakarta: Prenadamedia Group.

Murtining, H. (2018). Meningkatan Keterampilan Motorik Halus Melalui Kegiatan Menggunting Dengan Berbagai Media Pada Kelompok B Tk Dharma Wanita Tawangrejo. Jurnal Care : Children Advisory Research and Education. 6 (2). HIm 29.

Rakimahwati dkk. (2018). Pengaruh Kirigami Terhadap Kemampuan Motorik Halus Anak di Taman Kanak-Kanak. Jurnal Obsesi : Jurnal Pendidikan Anak Usia Dini. 2 (1). Hlm 103

Santrock, John W. 2007. Child Development (Alih Bahasa Oleh Mila Rahmawati Dan Anna Kuswandi) Edisi Kesebelas. Jakarta: Erlangga.

Sujiono. (2013). Konsep Dasar Paud. Jakarta: PT Indeks. 
Revalina Rizky Rinjany Sastra Miharja . PENINGKATAN KETERAMPILAN MOTORIK HALUS MELALUI PERMAINAN SAINS BILLON PADA KELOMPOK B (Penelitian Single Case Experimental pada Kelompok B TK Al Munawaroh Banjarsari). Early Childhood Vol. 4 No. 2, November 2020.

Sunanto, J, dkk. (2005). Pengantar Penelitian dengan Subyek Tunggal. CRICED University of Tsukuba

Suriantoso, A dkk. (2016). Meningkatkan Kemampuan Motorik Halus Melalui Permainan Playdough Pada Anak Kelompok Bermain Di Paud Tegaljaya. 1(1). Hlm 20.

Soetjiningsih. (1995). Tumbuh Kembang Anak. Jakarta : EGC

Tadkiroatun, M. (2008). Bermain Sambil belajar dan Mengasah Kecerdasan. Jakarta: Depdiknas.

Triharso, A. (2013). Permainan Kreatif dan Edukatif untuk Anak USia Dini. Yogyakarta : CV Andi Offset

Yulianti, D. (2010). Bermain Sambil Belajar Sains Di Taman Kanak-Kanak. Jakarta: PT.Indeks. 

Revalina Rizky Rinjany Sastra Miharja . PENINGKATAN KETERAMPILAN MOTORIK HALUS MELALUI PERMAINAN SAINS BILLON PADA KELOMPOK B (Penelitian Single Case Experimental pada Kelompok B TK Al Munawaroh Banjarsari). Early Childhood Vol. 4 No. 2, November 2020. 